\title{
The Quality Evaluation of Bilimbi Jelly Candy
}

\author{
Laili Hidayati, Olivia Christy Pereira \\ Department of Culinary \\ Universitas Negeri Malang \\ Malang, Indonesia \\ laili.hidayati.ft@um.ac.id
}

\begin{abstract}
The aim of this research was to analyze physical characteristics (color and texture), hedonic quality of taste and flavor of bilimbi jelly candy. There were 50 panelists in this research. This research was experimental research with two treatments, using bilimbi juice and smoothie, which were conducted in duplicate. Analysis method used in this research was $t$ Test. The result of the physical characteristics for color and texture of bilimbi jelly candy no difference. The result of the hedonic quality for taste was no difference and the hedonic quality for flavor was difference.
\end{abstract}

\section{Keywords - Bilimbi; Jelly Candy}

\section{INTRODUCTION}

Candy is one of many food products liked by many people, especially by children. Candies can be basically grouped into two, hard candy and chewy candy. One of the candies belongs to chewy candy is jelly candy. Jelly candy is a candy made from water or juice and gel-forming material that looks transparent and has a texture with a certain elasticity [1].

Jelly candy is one of the preferred types of confectionaries because it has a distinctive characteristic. The distinction lies in the taste, shape, elasticity and product elasticity [2]. Jelly candy made from fruits or vegetables has the advantage of nutritional value compared with those on the market that only come from the addition essence of chemical material.

Based on the research conducted by [1], it is showed that fruit or vegetable jelly candy has better nutritional value. Jelly candy made from sucrose and juice with a ratio of $4: 1$ with the addition of gelatin concentration of $6 \%$ has the best quality. Fruit juice used is tomatoes, watermelon, oranges, papaya, snake fruit (salak), apple or mango.

The making of jelly candy with fruit flavor that is often used is the taste of oranges, grapes, apples, seaweed, and strawberries. So far there has been no bilimbi-based candy. Bilimbi is one of fruits which spreads out widely in Indonesia. It also has many benefits, easy to find, but not yet widely used, as a basic ingredient of candy.

The utilization of bilimbi is currently still limited as a food flavoring ingredient. Many other ways that can be used in the processing of bilimbi so that it can be a qualified food commodity and has economic value, such as by processing it into jelly candy. Bilimbi jelly candy can be used as an alternative snack, especially candy that has economic value.

One of the ingredients of making jelly candy is water. Water can be replaced by extracting the bilimbi. The process of making bilimbi juice can be with either blender or juicer method. Making the bilimbi juice with blender method requires additional water, because the function of the blender is to refine the solid food, while the bilimbi juice making with juicer method does not need to add water, because juicer provides water extract by separating the residue of fruit or vegetable.

In the blending process, the fruit or vegetable fibers only get size reduction process (comminution), only refined. The amount of fiber content out of the blender is the same as the previous content when it enters the blender. In the juicer method, fruits or vegetables do not only get a fiber-refining process, but also a syringe. The drink produced by juicer is called juice, while the drink produced by blender is called smoothie [3].

Bilimbi (Averrhoa bilimbi) is one species in the star fruit family (Averrhoa).It is estimated that this plant is originated from the American region. This plant grows well in its native country while in Indonesia it is much cultivated in the yard and sometimes grows wildly in the fields or forest edges [4]. Bilimbi can bear fruit throughout the year and it is harvested three times a year. The bilimbi price in the market is $\mathrm{Rp}$ $5,000 / \mathrm{kg}$. Bilimbi has many benefits, such as reducing hypertension, whooping cough, bleeding gums, sprue, acne and tinea versicolor [4].

\section{METHOD}

The research was an experimental research, it was to see the quality difference of bilimbi jelly candy by using different bilimbi extract, bilimbi juice and bilimbi smoothie. Each treatment was repeated twice, then it was continued with physical test, quality test on both of bilimbi jelly candies and hedonic test. The panelists used were somewhat trained panelists totaling 50 people.

The ingredients of bilimbi jelly candy could be seen in Table 1 . The jelly candy making tools included digital scales, measuring cups, dough basin, blender, juicer, pans, stove, 
spoon, knife, ladle, and jelly mold. While the tools for color physical test was Color Reader and for texture test was Tensile Strength.

\section{TABLE 1. DEVELOPMENT RECIPE FOR BILIMBI JELLY CANDY}

\begin{tabular}{|l|l|l|}
\hline No. & Ingredients & Size \\
\hline 1. & Bilimbi & $100 \mathrm{cc}$ \\
2. & Gelatin & 20 gram \\
3. & Glucose & 50 gram \\
4. & Sugar & 100 gram \\
5. & Citric Acid & 1 gram \\
\hline
\end{tabular}

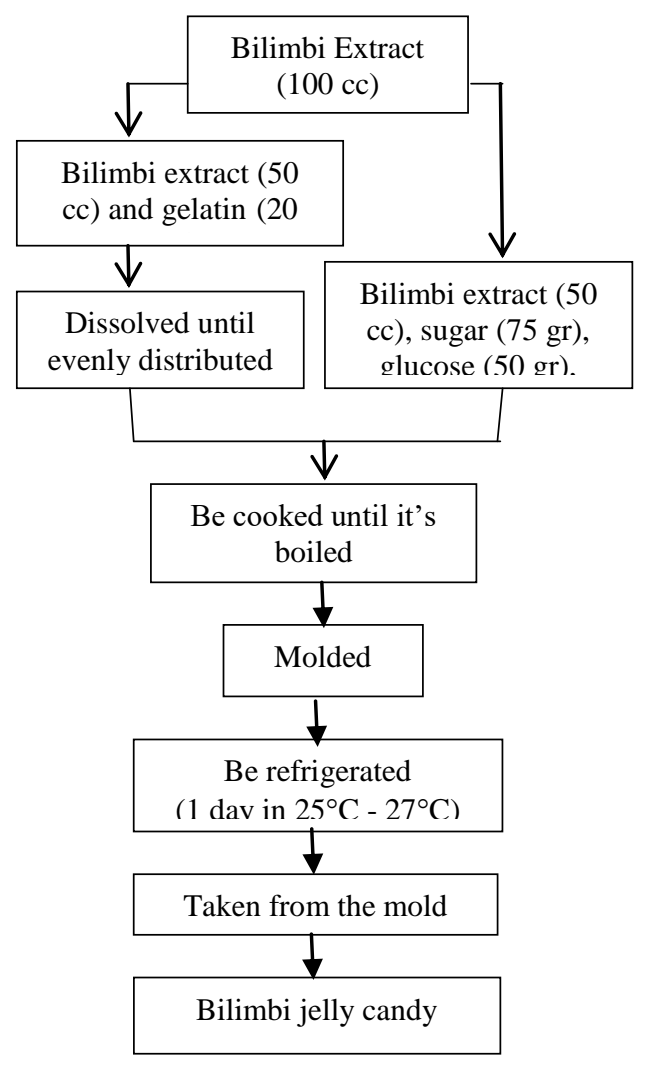

Fig.1 The steps of making bilimbi jelly candy could be seen in

\section{RESULT AND DISCUSSION}

\section{A. Physical color}

The results of physical test toward the color of bilimbi jelly candy could be seen in Figure 2 .

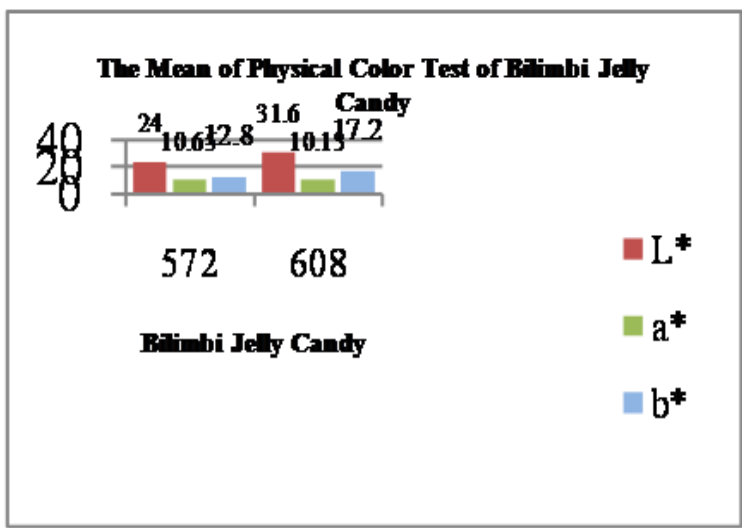

Fig 2. The Diagram of Physical Color Test of Bilimbi Jelly Candy

Notes:

572 : Bilimbi jelly candy using juice

608 : Bilimbi jelly candy using smoothie

The mean of brightness level color ( $\left.\mathrm{L}^{*}\right)$ on bilimbi jelly candy using juice and smoothie in Figure 2 was analyzed using $t$ test. The result of $t$ test analysis on the brightness level color $\left(\mathrm{L}^{*}\right)$ showed that $\mathrm{t}_{\text {calc }}<\mathrm{t}_{\text {tab }}$ was $(0.69)<(12.70)$. This indicated that there was no significant difference of the brightness level color $\left(\mathrm{L}^{*}\right)$ on the samples of bilimbi jelly candy using juice and using smoothie at 5\% significance level.

There was no significant difference of the brightness level color $\left(\mathrm{L}^{*}\right)$ on the samples of bilimbi jelly candy using juice and using smoothie because of the natural dyes influence derived from bilimbi as the basic ingredient of making jelly candy. According to [6], the dyes used in jelly candy making could be natural dyes (e.g. plant pigments) and synthetic dyes that were more resistant to treatment and making process.

The mean of reddish level color $\left(a^{*}\right)$ on bilimbi jelly candy using juice and smoothie in Figure 2 was analyzed using $t$ test. The result of $t$ test analysis on the reddish level color $\left(a^{*}\right)$ showed that $t_{\text {calc }}<t_{\text {tab }}$ was $(0.30)<(12.70)$. This indicated that there was no significant difference of the reddish level color $\left(a^{*}\right)$ on the samples of bilimbi jelly candy using juice and using smoothie at $5 \%$ significance level.

There was no significant difference of the reddish level color $\left(a^{*}\right)$ on the samples of bilimbi jelly candy using juice and using smoothie because of the same composition material on both types of jelly candies, i.e. bilimbi. It was supposed that there was influence of bilimbi natural color as the basic ingredient of bilimbi jelly candy. According to [7], the foodstuffs undergoing processing or heating could be predicted to experience a noticeable change in their color.

The mean of yellowish level color $\left(b^{*}\right)$ on bilimbi jelly candy using juice and smoothie in Figure 2 was analyzed using $t$ test. The result of $t$ test analysis on the yellowish level color $\left(b^{*}\right)$ showed that $t_{\text {calc }}<t_{\text {tab }}$ was $(0.64)<(12.70)$. This indicated that there was no significant difference of the 
yellowish level color $\left(b^{*}\right)$ on the samples of bilimbi jelly candy using juice and using smoothie at $5 \%$ significance level.

There was no significant difference of the yellowish level color $\left(b^{*}\right)$ on the samples of bilimbi jelly candy using juice and using smoothie because of the natural dyes influence derived from bilimbi as the basic ingredient of making jelly candy so that it made yellowish color on the bilimbi jelly candy. According to [5], raw bilimbi was green and it would be yellowish when it was ripe. Besides, the bilimbi flesh was white and greenish yellow. Indeed [6] stated that the attractive color was important because the color was a direct attraction of sales and affected the organoleptic response to flavor, which ultimately determined the consumers' acceptance.

\section{B. Physical texture}

The result of physical test on the texture of bilimbi jelly candy could be seen in Table 2 .

TABLE II. PHYSICAL TEST ON THE TEXTURE OF BILIMBI JELLY CANDY

\begin{tabular}{|l|l|l|l|l|}
\hline \multirow{2}{*}{ Sanple } & \multicolumn{2}{|c|}{ Repeated } & \multirow{2}{*}{ Total } & \multirow{2}{*}{ Mean } \\
\cline { 2 - 3 } & \multicolumn{2}{|c|}{$\mathrm{I}$} & & \\
\hline Juice & $3.4 \mathrm{~N}$ & $3.1 \mathrm{~N}$ & $6.5 \mathrm{~N}$ & $3.25 \mathrm{~N}$ \\
smoothie & $2.3 \mathrm{~N}$ & $2.5 \mathrm{~N}$ & $4.8 \mathrm{~N}$ & $2.4 \mathrm{~N}$ \\
\hline
\end{tabular}

The mean of physical texture on bilimbi jelly candy using juice and smoothie in Table 2 was analyzed using t test. The result of t test analysis on the physical texture on bilimbi jelly candy using juice and smoothie showed that $t_{\text {calc }}<t_{\text {tab }}$ was $(3.40)<(12.70)$. This indicated that there was no significant difference of the physical texture on the samples of bilimbi jelly candy using juice and using smoothie at $5 \%$ significance level.

There was no significant difference of the physical texture on the samples of bilimbi jelly candy using juice and using smoothie because of the same basic formula of making jelly candy and the addition of gelatin. The main function of adding gelatin in jelly candy making was to improve the elasticity, consistency and stability of the product [8]. According to [9], stated that an important component in jelly candy making was hydrocolloid components such as jelly, gelatin, carrageenan, gums, pectin, and starch which were also used to modify the texture. Texture was an important aspect of the food quality, sometimes more important than smell, taste, and color [10].

\section{Taste Quality}

The mean of hedonic taste quality test of bilimbi jelly candy using juice was 3.46 and using smoothie was 3.2 in which they were both analyzed using t test. The result of t test analysis on the hedonic taste quality on bilimbi jelly candy using juice and smoothie showed that $t_{\text {calc }}<t_{\text {tab }}$ was $(1.27)<(2.01)$. This indicated that there was no significant difference of the hedonic taste quality on the samples of bilimbi jelly candy using juice and using smoothie at 5\% significance level.
There was no significant difference of the taste on the samples of bilimbi jelly candy using juice and using smoothie because it was influenced by the basic ingredient of jelly candy, i.e. bilimbi. Bilimbi flesh had more dominant sour taste [11]. Taste was influenced by several factors: chemical compounds, temperature, concentratration, and interaction with other taste components. Everyone has the lowest concentration limit of a taste so it could be still felt [12].

\section{Flavor Quality}

The mean of hedonic flavor quality on bilimbi jelly candy using juice was 4.14 and using smoothie was 3 in which they were both analyzed using t test. The result of $t$ test analysis on the hedonic flavor quality on bilimbi jelly candy using juice and smoothie showed that $\mathrm{t}_{\text {calc }}<\mathrm{t}_{\text {tab }}$ was $(5.642)<(2.0105)$. This indicated that there was no significant difference of the hedonic flavor quality on the samples of bilimbi jelly candy using juice and using smoothie at 5\% significance level.

There was significant difference of the hedonic flavor (aroma) quality on the samples of bilimbi jelly candy using juice and using smoothie because of the different bilimbi extract making process, i.e. using juicer and blender. The way how juicers work was providing water extract by separating the fruit pulp, while the blender was size reduction process (comminution), only refined [3]. Therefore, the extract produced by juicer (juice) did not need to be strained anymore, unlike the extract produced by blender (smoothie) in which it needed to be strained again to get good bilimbi extract. Aroma (flavor) or odor could be recognized when it was in the form of fume and molecular component, both of which had to touch the cilia of olfactory receptor cells [12].

\section{E. Hedonic Taste Test}

The mean of hedonic taste test on bilimbi jelly candy using juice was 3.42 and using smoothie was 3.14 in which they were both analyzed using $t$ test. The result of $t$ test analysis on the hedonic taste on bilimbi jelly candy using juice and smoothie showed that $\mathrm{t}_{\text {calc }}<\mathrm{t}_{\text {tab }}$ was $\mathrm{s}(1.52)<(2.01)$. This indicated that there was no significant difference of the hedonic taste on the samples of bilimbi jelly candy using juice and using smoothie at 5\% significance level.

There was no significant difference of the taste preferences on the samples of bilimbi jelly candy using juice and using smoothie because the taste of bilimbi was more dominant, in addition to the additional sugar and citric acid. The flesh of bilimbi had more dominant sour taste [11]. The taste, indeed, involved the five senses more, i.e. tongue [12]. In the candy making, sugar served to provide sweetness and softness that had high solubility, having the ability to decrease water activity $\left(a_{w}\right)$ and bind water [1]. The taste extremely affected the organoleptic response and consumers' acceptance toward the products [6]. 


\section{F. Hedonic Color Test}

The mean of hedonic color test on bilimbi jelly candy using juice was 4.66 and using smoothie was 3.82 in which they were both analyzed using $t$ test.The result of $t$ test analysis on the hedonic color on bilimbi jelly candy using juice and smoothie showed that $t_{\text {calc }}>t_{\text {tab }}$ was $(5.95)>(2.01)$. This indicated that there was significant difference of the hedonic color on the samples of bilimbi jelly candy using juice and using smoothie at $5 \%$ significance level.

There was significant difference of the color preferences on the samples of bilimbi jelly candy using juice and using smoothie. This might be caused by the result of different making of bilimbi jelly candy. The color produced by bilimbi jelly candy using juice was clearer yellow compared to bilimbi jelly candy using smoohie. According to [7], the foodstuffs undergoing processing or heating could be predicted to experience a noticeable change in their color. The important quality parameter in making candy was color or appearance [13]. Color was the first indicator seen and observed by the consumers because the color was a visible factor that could be directly seen by them [10].

\section{G. Hedonic Texture Test}

The mean of hedonic texture test on bilimbi jelly candy using juice was 4.34 and using smoothie was 3.78 in which they were both analyzed using $t$ test. The result of $t$ test analysis on the hedonic texture on bilimbi jelly candy using juice and smoothie showed that $t_{\text {calc }}>t_{\text {tab }}$ was (3.35)>(2.01). This indicated that there was significant difference of the hedonic texture on the samples of bilimbi jelly candy using juice and using smoothie at $5 \%$ significance level.

There was significant difference of the texture preferences on the samples of bilimbi jelly candy using juice and using smoothie because of the result of different making of bilimbi jelly candy, i.e. using juicer and blender. Drinks produced by juicer were called as juice. Juicer gave water extract and nutrition of the fruit and vegetable by separating its pulp. Drinks produced by juicer were called as smoothie. Unlike juice, smoothie consisted of the whole part of fruit or vegetable including its rind and fibers so that the texture was thicker than juice [3]. Therefore, bilimbi jelly candy using smoothie had thicker and chewier texture compared to bilimbi jelly candy using juice

\section{H. Hedonic Flavor Test}

The mean of hedonic flavor test on bilimbi jelly candy using juice was 2.92 and using smoothie was 2.36 in which they were both analyzed using $t$ test. The result of $t$ test analysis on the hedonic aroma (flavor) on bilimbi jelly candy using juice and smoothie showed that $t_{\text {calc }}>t_{\text {tab }}$ was $(2.66)>(2.01)$. This indicated that there was significant difference of the hedonic aroma (flavor) on the samples of bilimbi jelly candy using juice and using smoothie at 5\% significance level.

There was significant difference of the flavor preferences on the samples of bilimbi jelly candy using juice and using smoothie because of the result of different making of bilimbi jelly candy, i.e. using juicer and blender. The way how juicers work was providing water extract by separating the fruit pulp, while the blender was size reduction process (comminution), only refined [3]. Bilimbi jelly candy using juice had stronger aroma (flavor) compared to bilimbi jelly candy using smoohie. Odor or aroma (flavor) had more difficult sensory characteristics to be classified and explained because of its wide variety [14].

\section{CONCLUSION}

The results of color test (brightness level) $\mathrm{L}^{*}$, (reddish level) $a^{*}$, (yellowish level) $b^{*}$, physical texture, hedonic taste quality, showed no significant difference and hedonic flavor quality test showed significant difference between bilimbi jelly candy using bilimbi juice and bilimbi jelly candy using bilimbi smoothie.

The result of hedonic test showed that there were differences in terms of color, texture, and flavor between bilimbi jelly candy using bilimbi juice and bilimbi jelly candy using bilimbi smoothie.

\section{REFERENCES}

[1] Hidayat, Nur dan Ken Ikariztiana. Membuat Permen Jelly. Surabaya: Trubus Agrisarana. 2004.

[2] Hambali. E., A. Suryani dan Wadli. Membuat Aneka Olahan Rumput Laut. Jakarta: Penebar Swadaya. 2004.

[3] Sholekhudin, M. Menu Sehat. Edisi 10/V/07 (http://kesehatanvegan.com/2010/01/29/pilih-yang-segar-diblender-ataudijus). 2010.

[4] Thomas, A.N.S. Tanaman Obat Tradisional 2, Yogyakarta: Kanisius. 2007

[5] Wijayakusuma, Hembing. Ramuan Lengkap Herbal Taklukkan Penyakit. Jakarta: Pustaka Bunda. 2008.

[6] Koswara, Sutrisno. Teknologi Pembuatan Permen. Ebookpangan. 2009.

[7] Desrosier, NormanW. 2008. Teknologi Pengawetan Pangan. Jakarta: Penerbit Universitas Indonesia (UI-Press).

[8] Jaswir I. Memahami Gelatin. Artikel Iptek.http//www.duniapangankita.file.wordpress.com/gelatin.pdf. 2007.

[9] Wahyuni, R.Pemanfaatan Dan Pengolahan Kulit Buah Naga Super Merah. Skripsi Universitas Brawijaya. Malang. 2010.

[10] Pranata, Sinung., Purwajatiningsinh, Ekawati, Oktaviana Putri. Kualitas Permen Jelly dari Albedo Kulit Jeruk Bali dan Rosela dengan Penambahan Sorbitol. Fakultas Teknobiologi Universitas Atma Jaya Yogyakarta. 2010

[11] Wirakusumah, Emma. Jus Buah dan Sayuran. Jakarta: Penebar wadaya.2005.

[12] Winarno, F. G. Kimia Pangan dan Gizi. Jakarta: Gramedia. 2004

[13] Sularjo. Pengaruh Perbandingan Gula Pasir dan Daging Buah Terhadap Kualitas Permen Pepaya. Universitas Widya Dharma Klaten. 2010.

[14] Setyaningsih, D., Apriyantono, P. \& Sari, M. Analisis Pangan Sensori Untuk Industri Pangan Dan Argo. Bogor: IPB Press. 2010. 